\title{
Effect of Ethylene and Carbon Dioxide on Seed Germination of Monochoria vaginalis var. plantaginea*
}

\author{
Yoshie S. Momonoki**
}

\begin{abstract}
The relationship between seed germination of Monochoria vaginalis var. plantaginea and gas composition in soil, i.e. ethylene, $\mathrm{CO}_{2}, \mathrm{O}_{2}$ and their combination was studied. A high germination percentage was obtained in the presence of both ethylene and $\mathrm{CO}_{2}$ regardless of the storage conditions, but in the presence of absorbents for both ethylene and $\mathrm{CO}_{2}$ the germination percentage declined significantly (Fig. 2 and Table 1 ). In the presence of $\mathrm{CO}_{2}$ absorbent, the application of ethylene to seed increased the germination percentage, while the effect of exogenous $\mathrm{CO}_{2}$ with the absorbent of ethylene on seed germination was very little. However, the germination percentage was increased by exogenous $\mathrm{CO}_{2}$ if the concentration was sufficiently high (Table 1 ). The effect of ethylene on seed germination of Monochoria may more important than that of $\mathrm{CO}_{2}$, and the seed germination is considered to be increased by endogenous ethylene.
\end{abstract}

The seeds under $60 \%$ oxygen exhibited a significantly decreased germination percentage while under $0.2 \%$ oxygen they showed high germination. No seeds, even non-dormant seeds, germinated in a petri dish with a filter paper in the presence of $21 \%$ oxygen (Fig. 1). The results demonstrate that Monochoria seeds require very little oxygen for germination.

Key words : $\mathrm{C}_{2} \mathrm{H}_{4}, \mathrm{CO}_{2}$, germination, Monochoria

* Experimental results reported herein were presented at the 18th Annual Conference of the Weed Science Society of Japan in 1979.

** Faculty of Bioindustry, Tokyo University of Agriculture, Abashiri, Hokkaido 09924, Japan.

(Received October 28, 1991) seeds, $\mathrm{O}_{2}$

\section{Introduction}

Monochoria vaginalis (Burm. f.) Presl var. plantaginea (Roxb.) Salms-Laub (hereafter Monochoria) is a typical hydrophytic, annual broadleaved weed. The increase in annual paddy weeds due to a shifting herbicide resistance of weeds and careless water control in paddy fields has recently become an issue ${ }^{16}$. The mechanism of germination and dormancy of Monochoria is still little understood. An earlier paper by Chisaka and Kataoka ${ }^{1)}$ reported that a high germination percentage of Monochoria was obtained from seeds illuminated by light, incubated in a glass container sealed with a rubber stopper to maintain low oxygen (below 1\%), and exposed to ethylene $(10 \mathrm{ppm})$. Also, Kataoka and $\mathrm{Kim}^{9)}$ reported that Monochoria seeds showed higher germination rate under low oxygen partial pressure than in the atmosphere. In fact, Monochoria seeds have been observed to germinate well in flooded paddy fields. It is known that exogenous ethylene or $\mathrm{CO}_{2}$ stimulates growth of both axes and cotyledons in seeds ${ }^{2)}$, and one action of $\mathrm{CO}_{2}$ in breaking dormancy of the seeds is their growth promotion by stimulating ethylene production ${ }^{4}$. In many other species, the presence of $\mathrm{CO}_{2}$ during the early stages of imbibition of dormant seeds was necessary for the ethylene action ${ }^{3,4,13 \sim 15)}$. Jackson $^{7)}$ suggests that endogenously produced ethylene may be supplemented by environmental ethylene produced in flooded soil. Flooded soil produces most ethylene when the supply of oxygen is restricted to $1 \mathrm{KPa}$ or less ${ }^{17}$, and there is an 
increasing rate of ethylene production with temperature $\left(5-65^{\circ} \mathrm{C}\right)$ in soil with a high organic matter content ${ }^{5}$. In well-aerated soil, on the other hand, ethylene is metabolized or absorbed by grampositive mycobacteria ${ }^{7)}$. Thus, the balance between formation and degradation would determine how much dissolved ethylene is present in the soil. In these circumstances, seed germination may be affected by gaseous condition of the paddy field.

In this study, we inventigated the relationship between seed germination of Monochoria and gas phase composition, i.e. ethylene, $\mathrm{CO}_{2}$ and their combination.

\section{Materials and Methods}

\section{Seed materials}

Seeds collected at the experimental paddy fields of the National Institute of Agricultural Science, Konosu from the end of September through the end of October in 1978 were carefully selected and stored under different conditions according to the purpose of the experiment at the beginning of November. Most experiments were carried out from 1978 through 1980 at the National Institute of Agricultural Science.

\section{Germination test}

In all germination tests, 100 seeds were placed in each petri dish or glass tube. Seed germination was carried out under 3,000 lux of light at $30^{\circ} \mathrm{C}$ for 5-6 days. The germination test was repeated 2 or 3 times in each experiment.

\section{Determination of $\mathrm{C}_{2} \mathrm{H}_{4}, \mathrm{CO}_{2}$ and $\mathrm{O}_{2}$}

The concentration of ethylene was determined by a gas chromatograph equipped with a flame ionization detector (FID). The glass column (2 $\mathrm{m} \times 0.3 \mathrm{~mm}$ i.d.) was packed with Porapak Q. Carrier gas was $\mathrm{N}_{2}(40 \mathrm{ml} / \mathrm{min})$, and temperatures were $100^{\circ} \mathrm{C}$ for injection and $80^{\circ} \mathrm{C}$ for column. Concentrations of $\mathrm{CO}_{2}$ and oxygen were detected by a gas chromatograph equipped with a thermal conductivity detector (TCD). The stainless steel column was $1 \mathrm{~m} \times 0.3 \mathrm{~mm}$ (i.d.) packed with either molecular sieves $5 \mathrm{~A}$ for $\mathrm{CO}_{2}$ or Porapak $\mathrm{Q}$ for oxygen. Carrier gas for both gases was He (40 $\mathrm{ml} / \mathrm{min}$ ), temperatures were at $70^{\circ} \mathrm{C}$ for injection and detector, and the column was at $50^{\circ} \mathrm{C}$. One milliliter of gas sample was injected for all gas determinations.

\section{Experiment I : Effect of storage on seed ger- mination}

The experiment was carried out to investigate the effects of seed storage and the time elapsed after harvest on seed germination under various seed beds. Seeds were stored under 3 different conditions as follows: (1) Dry condition at $5^{\circ} \mathrm{C}$ (seeds were stored in a desiccator which was placed in a $5^{\circ} \mathrm{C}$-cold room as the control); (2) Moist condition at $5^{\circ} \mathrm{C}$ (seeds were stored in a covered petri dish on moist filter paper which was placed in a $5^{\circ} \mathrm{C}$-cold room); (3) Field condition (the bottom of a Wagner pot $(1 / 10,000$ a) was removed and covered with a fine netted nylon cloth. Seeds were mixed with soil sieved through a fine mesh and the mixture was placed on the netted nylon colth bottom and covered with soil to a depth of $2-3 \mathrm{~cm}$. The soil that was mixed with seeds had beed treated at $50-60^{\circ} \mathrm{C}$ for $48 \mathrm{~h}$ to kill other kinds of seeds. The pot was then buried in a paddy field).

Seed germination was tested using 4 methods. (A) Seeds were germinated in a petri dish on moist filter paper ; (B) Seeds were placed in a 55 ml-glass tube $(7.5 \mathrm{~cm}$ in height) with water to a depth of $1 \mathrm{~cm}$; (C) Seeds were placed in a $55 \mathrm{ml}^{-}$ glass tube with a wet filter paper on the bottom and filled with nitrogen $\left(99.6 \% \mathrm{~N}_{2}\right)$ instead of air ; (D) Seeds were placed on the surface of $1 \mathrm{~cm}$ of water-saturated soil in a $55 \mathrm{ml}$-glass tube. The glass tube used for the germination test was sealed with a rubber stopper.

Experiment II : Effects of storage and gas phase composition on seed germination

The experiment was conducted to determine the effects of storage and gas combination of oxygen, ethylene or $\mathrm{CO}_{2}$ on germination. Seeds 
stored under dry and moist conditions at $5^{\circ} \mathrm{C}$ as described previously for about 2 months were used in this experiment. They were placed in a $55 \mathrm{ml}$-glass tube with wet filter paper on the bottom for germination. The gas composition was adjusted as follows: A-1) Ambient air (21\% $\mathrm{O}_{2}$ ) with and without absorbents of ethylene and $\mathrm{CO}_{2}$ were used for the controls. The absorbents used were $0.25 \mathrm{M} \mathrm{Hg}\left(\mathrm{ClO}_{4}\right)_{2}$ for ethylene and $20 \%$ $\mathrm{KOH}$ solution for $\mathrm{CO}_{2}$. A-2) In the presence of $\mathrm{CO}_{2}$ absorbent, air plus $50 \mathrm{ppm}$ ethylene. A-3) In the presence of ethylene absorbent, air plus $5 \%$ $\mathrm{CO}_{2}$. A-4) Without absorbents, air plus $50 \mathrm{ppm}$ ethylene and $5 \% \mathrm{CO}_{2}$. In air with absorbents, concentrations of ethylene and $\mathrm{CO}_{2}$ measured were $0 \mathrm{ppm}$ and $0 \%$. In air without absorbents, the concentrations of ethylene and $\mathrm{CO}_{2}$ measured were $0.08 \pm 0.01 \mathrm{ppm}$ (mean of 3 experiments \pm $\mathrm{SE})$ and $0.2 \pm 0.04 \%$, respectively. Injected 50 ppm ethylene and $5 \% \mathrm{CO}_{2}$ measured were $50 \pm 0.5$ ppm and $5 \pm 0.2 \%$. B-1) A zero percent oxygen environment with and without absorbents of ethylene and $\mathrm{CO}_{2}$ was generated by replacing air with nitrogen. B-2) In the presence of $\mathrm{CO}_{2}$ absorbent, $0 \%$ oxygen plus $50 \mathrm{ppm}$ ethylene. $\mathrm{B}-$ 3 ) In the presence of ethylene absorbent, $0 \%$ oxygen plus $5 \% \mathrm{CO}_{2}$. B-4) Without absorbents, $0 \%$ oxygen plus $50 \mathrm{ppm}$ ethylene and $5 \% \mathrm{CO}_{2}$. In zero percent oxygen, concentration of oxygen measured was $0.2 \% \quad \mathrm{O}_{2}\left(99.8 \% \mathrm{~N}_{2}\right)$. Concentrations of injected $50 \mathrm{ppm}$ ethylene and $5 \% \mathrm{CO}_{2}$ measured were $50 \pm 0.3 \mathrm{ppm}$ and $4 \pm 0.2 \%$. C-1) Sixty percent of oxygen with and without absorbents of ethylene and $\mathrm{CO}_{2}$. Oxygen was mixed with air to achieve a gas phase of $60 \%$ oxygen. $\mathrm{C}-2$ ) In the presence of $\mathrm{CO}_{2}$ absorbent, $60 \%$ oxygen plus $50 \mathrm{ppm}$ ethylene. $\mathrm{C}-3$ ) In the presence of ethylene absorbent, $60 \%$ oxygen plus $5 \% \mathrm{CO}_{2}$. C-4) Without absorbents, $60 \%$ oxygen plus 50 ppm ethylene and $5 \% \mathrm{CO}_{2}$. Injected $60 \%$ oxygen measured was $60 \pm 2 \% \mathrm{O}_{2}$. Injected 50 ppm ethylene and $5 \% \mathrm{CO}_{2}$ measured were $50 \pm 0.6 \mathrm{ppm} \mathrm{C}_{2} \mathrm{H}_{4}$ and $4 \pm 0.4 \% \mathrm{CO}_{2}$. After gas was injected into the sealed glass tube containing seeds, all gas concentrations were immediately checked. A small glass tube containing wet filter paper with an absorbent solution of ethylene or $\mathrm{CO}_{2}$ was placed in a $55 \mathrm{ml}$-glass tube.

Experiment III : Effects of gas concentrations of ethylene and carbon dioxide on seed germination

To study the effects of seed storage and gas concentration of ethylene and $\mathrm{CO}_{2}$ on seed germination, seeds stored under dry and moist conditions at $5^{\circ} \mathrm{C}$ for about 2 months were used. They were placed on a dampened filter paper raised like a platform using a glass container which was placed upside down in a $55 \mathrm{ml}$-glass tube for germination. In all glass tubes, ambient air (21\% $\mathrm{O}_{2}$ ) was the concentration of oxygen. Injected ethylene concentrations measured were $0.7 \pm 0.05$ ppm (mean of 2 experiments $\pm \mathrm{SE}$ ), $8 \pm 0.5 \mathrm{ppm}$ and $35 \pm 2 \mathrm{ppm}$, respectively. Gas combination was paired with each ethylene concentration in all $\mathrm{CO}_{2}$ concentrations. Injected $\mathrm{CO}_{2}$ concentrations measured were $0.1 \pm 0.05 \%$ (mean of 2 experiments \pm SE), $0.3 \pm 0.05 \%, 1 \pm 0.15 \%$ and $4 \pm 0.35 \%$, respectively. Ambient air with and without the two absorbents of ethylene and $\mathrm{CO}_{2}$ was used as the control. After gas was injected into the sealed $55 \mathrm{ml}$-glass tube containing seeds, all gas concentrations were immediately checked.

\section{Results}

\section{Effect of seed storage conditions on seed germination}

Effects of storage on seed germination are shown in Fig. 1. Seeds immediately after harvest did not germinate under any of the four germination conditions. Seeds 6 weeks after storage under a dry condition at $5^{\circ} \mathrm{C}$ showed germination of over $50 \%$. On the other hand, over $70 \%$ of seed germination was found in seeds 2 weeks after storage under a moist condition at the same temperature and in an outdoor field.

No seeds from any of the storage conditions 


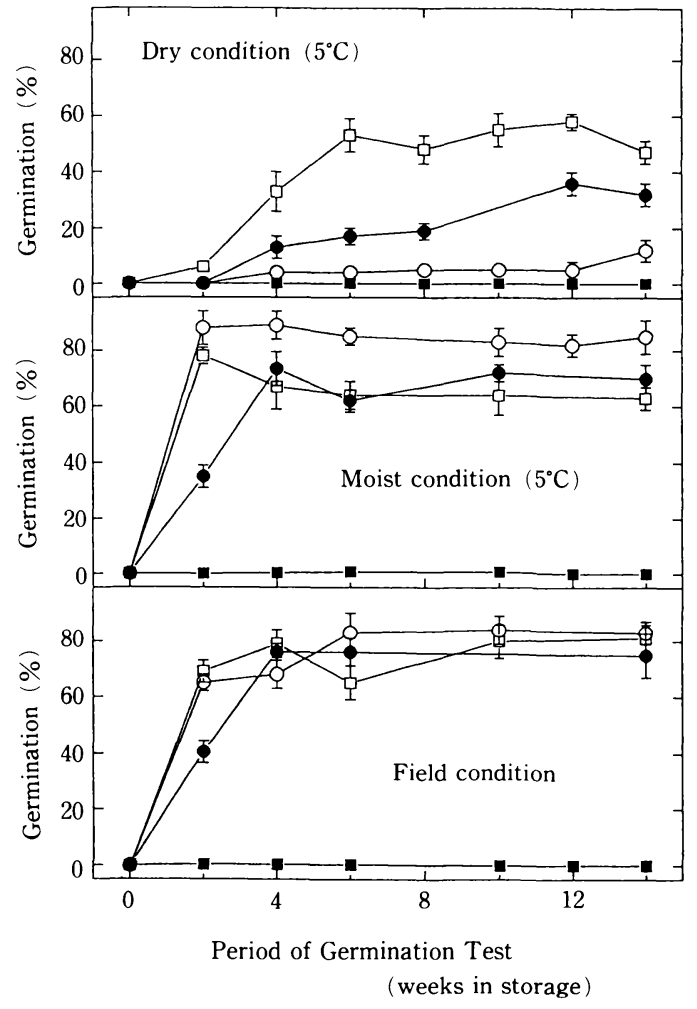

Fig. 1. Changes in the germination percentage of Monochoria seeds during various periods under three different storage conditions.

Seed storage began on 1st November under three conditions. Germination was tested by the following 4 methods.

a, aerobic (air) condition; $\odot$, flooding condition ; $\square$, anaerobic $\left(\mathrm{N}_{2}\right)$ condition; $\bullet$, soil condition.

See details of the storage and germination conditions in the text.

All glass tubes were sealed with a rubber stopper.

Each point is the mean of 3 experiments $( \pm S E)$.

germinated on wet filter paper with atmosphere as the air condition, while seeds from all the conditions showed a high germination percentage in the sealed glass tube with a low oxygen $(0.2 \%)$ level. When stored under a dry condition under the gas phase replaced with nitrogen seeds, germination percentage increased dramatically compared to the other germination beds. Additionally, the seeds stored under any of the conditions did not germinate in the dark until about 4-
5 months after harvest (data not shown).

Effect of storage and gas phase composition on seed germination

Figure 2 shows the effect of ethylene and $\mathrm{CO}_{2}$ in combination with various concentrations of oxygen on the germination of seeds stored under different conditions. All conditions of storage showed an increased germination under a low oxygen $(0.2 \%)$ condition and a decrease in germination percentage under a high oxygen $(60 \%)$ condition. There was a difference in seed response to ethylene and $\mathrm{CO}_{2}$ depending on conditions of storage. In the control without the two absorbents of ethylene and $\mathrm{CO}_{2}$, seeds stored under a dry condition at $5{ }^{\circ} \mathrm{C}$ showed only $12 \%$ germination under an air $\left(21 \% \mathrm{O}_{2}\right)$ condition and $25 \%$ under low oxygen. While those stored under a moist condition at the same temperature showed $69 \%$ under air and $55 \%$ under $0.2 \%$ oxygen conditions. Seed germination was enhanced by exogenous ethylene and $\mathrm{CO}_{2}$ under any oxygen concentration, even as high as $60 \%$. However, in the presence of both the absorbents ethylene and $\mathrm{CO}_{2}$, the germination percentage significantly declined. Gas combined with $50 \mathrm{ppm}$ ethylene and 4 or $5 \% \mathrm{CO}_{2}$ under air caused an increased in germination of seeds stored under in dry and moist conditions at $5^{\circ} \mathrm{C}$ from $8 \%\left(0 \mathrm{ppm} \mathrm{C}_{2} \mathrm{H}_{4}, 0 \%\right.$ $\left.\mathrm{CO}_{2}\right)$ to $68 \%$ and from $15 \%\left(0 \mathrm{ppm} \mathrm{C}_{2} \mathrm{H}_{4}, 0 \% \mathrm{CO}_{2}\right)$ to $83 \%$, respectively.

\section{Effects of gas concentrations of ethylene and} carbon dioxide on seed germination

The effects of combinations of ethylene and $\mathrm{CO}_{2}$ on seed germination using seeds stored under dry and moist conditions at $5^{\circ} \mathrm{C}$ are shown in Table 1. In a combined gas treatment of ethylene and $\mathrm{CO}_{2}$, seed germination increased. However, there was a difference in effect of ethylene and $\mathrm{CO}_{2}$ on germination depending on storage conditions. In seeds stored under a dry condition at $5^{\circ} \mathrm{C}$, germination of over $60 \%$ was obtained by application of $0.7-35 \mathrm{ppm}$ ethylene plus $4 \% \mathrm{CO}_{2}$. In seeds stored under other conditions, over $60 \%$ 


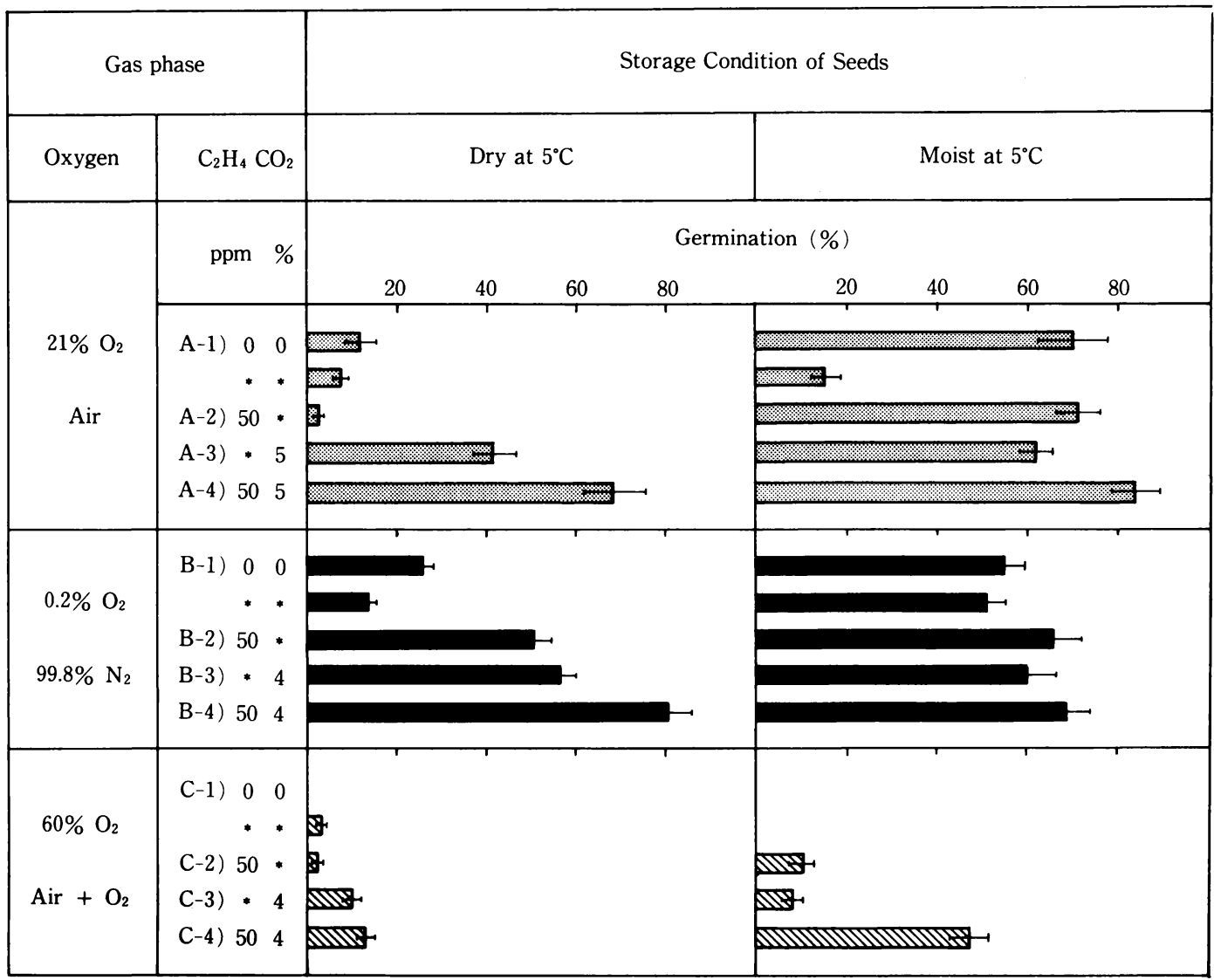

Fig. 2. Effects of ethylene, $\mathrm{CO}_{2}$ or their combination and two storage conditions on the germination of Monochoria seeds.

- The absorbents used were $0.25 \mathrm{M} \mathrm{Hg}\left(\mathrm{ClO}_{4}\right)_{2}$ for $\mathrm{C}_{2} \mathrm{H}_{4}$ and $20 \% \mathrm{KOH}$ for $\mathrm{CO}_{2}$.

To test germination : after 2 months in storage, the seeds were placed on wet filter paper in a $55 \mathrm{ml}$-glass tube which was sealed with a rubber stopper.

Each point is the mean of 3 experiments $( \pm \mathrm{SE}$ ).

See $<$ Experiment II $>$ for detail of gas composition.

germination was obtained by $8-35 \mathrm{ppm}$ ethylene plus $0.1-4 \% \mathrm{CO}_{2}$, or $0.3 \% \mathrm{CO}_{2}$ or by $0.7-35 \mathrm{ppm}$ ethylene plus $1-4 \% \mathrm{CO}_{2}$ or $0-35 \mathrm{ppm}$ ethylene plus $4 \% \mathrm{CO}_{2}$. In the presence of the absorbent of $\mathrm{CO}_{2}$, the seeds were induced to germinate by ethylene. However, in the presence of the absorbent of ethylene, $\mathrm{CO}_{2}$ had minimal effect on germination.

\section{Discussion}

The response of Monochoria seeds to ethylene or $\mathrm{CO}_{2}$ depends upon their storage conditions.
About 2 months storage under a dry condition at $5^{\circ} \mathrm{C}$ seems to maintain a seed dormancy compared to the other storage conditions (i.e., a moist condition at $5^{\circ} \mathrm{C}$ or a field condition). Seeds showed a significant response only to high concentrations of both ethylene and $\mathrm{CO}_{2}$. On the other hand, those stored under a moist condition, which seems to promote a loss of seed dormancy were significantly affected by low concentrations of ethylene and $\mathrm{CO}_{2}$. The highest germination percentage of seeds stored under both conditions was 
Table 1. Effect of ethylene and $\mathrm{CO}_{2}$ on seed germination of Monochoria.

\begin{tabular}{|c|c|c|c|c|c|c|}
\hline \multirow{2}{*}{$\begin{array}{l}\text { Storage } \\
\text { of Seeds }\end{array}$} & \multirow{2}{*}{$\begin{array}{c}\text { Initial } \\
\text { Concentration } \\
\text { of } \mathrm{C}_{2} \mathrm{H}_{4}\end{array}$} & \multicolumn{5}{|c|}{ Initial Concentration of $\mathrm{CO}_{2} \%$} \\
\hline & & $\mathrm{KOH}$ & 0.1 & 0.3 & 1 & 4 \\
\hline \multirow{6}{*}{$\begin{array}{l}\text { Dry } \\
\text { Condition } \\
\text { at } 5^{\circ} \mathrm{C}\end{array}$} & ppm & \multicolumn{4}{|c|}{ Germination \% } & \\
\hline & $\mathrm{Hg}\left(\mathrm{ClO}_{4}\right)_{2}$ & $1.5 \pm 0.5$ & $0.0 \pm 0.0$ & $0.5 \pm 0.5$ & $0.5 \pm 0.5$ & $1.0 \pm 0.0$ \\
\hline & 0.0 & $0.5 \pm 0.5$ & $1.5 \pm 0.5$ & $2.0 \pm 1.0$ & $1.5 \pm 0.5$ & $45.5 \pm 5.5$ \\
\hline & 0.7 & $1.5 \pm 0.5$ & $3.5 \pm 0.5$ & $4.0 \pm 1.0$ & $9.0 \pm 1.5$ & $63.0 \pm 4.0$ \\
\hline & 8 & $2.5 \pm 0.5$ & $7.0 \pm 1.0$ & $4.5 \pm 1.5$ & $1.5 \pm 4.5$ & $72.0 \pm 7.0$ \\
\hline & 35 & $4.0 \pm 0.0$ & $18.0 \pm 2.0$ & $20.5 \pm 3.5$ & $50.0 \pm 9.0$ & $88.0 \pm 8.0$ \\
\hline \multirow{5}{*}{$\begin{array}{l}\text { Moist } \\
\text { Condition } \\
\text { at } 5^{\circ} \mathrm{C}\end{array}$} & $\mathrm{Hg}\left(\mathrm{ClO}_{4}\right)_{2}$ & $1.5 \pm 0.5$ & $0.0 \pm 0.0$ & $0.0 \pm 0.0$ & $5.5 \pm 0.5$ & $38.0 \pm 3.0$ \\
\hline & 0.0 & $4.5 \pm 0.5$ & $6.5 \pm 1.5$ & $31.0 \pm 2.0$ & $48.5 \pm 6.5$ & $72.0 \pm 4.0$ \\
\hline & 0.7 & $16.0 \pm 3.0$ & $49.0 \pm 4.0$ & $52.5 \pm 4.5$ & $71.0 \pm 3.0$ & $73.0 \pm 4.0$ \\
\hline & 8 & $48.0 \pm 3.0$ & $68.0 \pm 4.0$ & $61.5 \pm 4.5$ & $63.5 \pm 3.5$ & $70.0 \pm 5.0$ \\
\hline & 35 & $50.0 \pm 6.0$ & $80.0 \pm 14.0$ & $64.0 \pm 6.0$ & $73.5 \pm 5.5$ & $76.5 \pm 3.5$ \\
\hline
\end{tabular}

\footnotetext{
a) Mean of 2 experiments $( \pm \mathrm{SE})$.

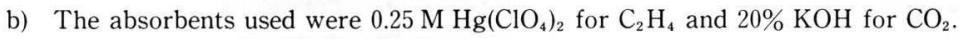

c) In all glass tubes, ambient air $\left(21 \% \mathrm{O}_{2}\right)$ was used.

d) To test germination: After 2 months in storage, the seeds were placed on wet filter paper in a glass tube sealed with a rubber stopper.
}

obtained in the combined presence of the two gases (ethylene and $\mathrm{CO}_{2}$ ), while in the presence of absorbents of these gases, germination percentage declined significantly. In the presence of the absorbent of $\mathrm{CO}_{2}$, seeds were induced to germinate by ethylene. However, the effect of $\mathrm{CO}_{2}$ in the presence of the absorbent of ethylene on germination was slight. The results appear to indicate that the effect of ethylene on seed germination is more significant than that of $\mathrm{CO}_{2}$.

The stimulus of seed germination by ethylene and the effect of $\mathrm{CO}_{2}$ on ethylene production is well known ${ }^{3,4,6 \sim 8,10)}$. In fact, Monochoria seeds require little oxygen for germination. Under $60 \%$ oxygen, the seeds stored under any of the conditions exhibited a significantly decreased germination percentage, while under $0.2 \%$ oxygen germination was high whatever the condition of storage.

Yang and Hoffmann ${ }^{19)}$ noted that the concentrations of $\mathrm{CO}_{2}$ giving half maximal promotion of 1aminocyclopropane-carboxylic acid (ACC)dependent ethylene production are only several-

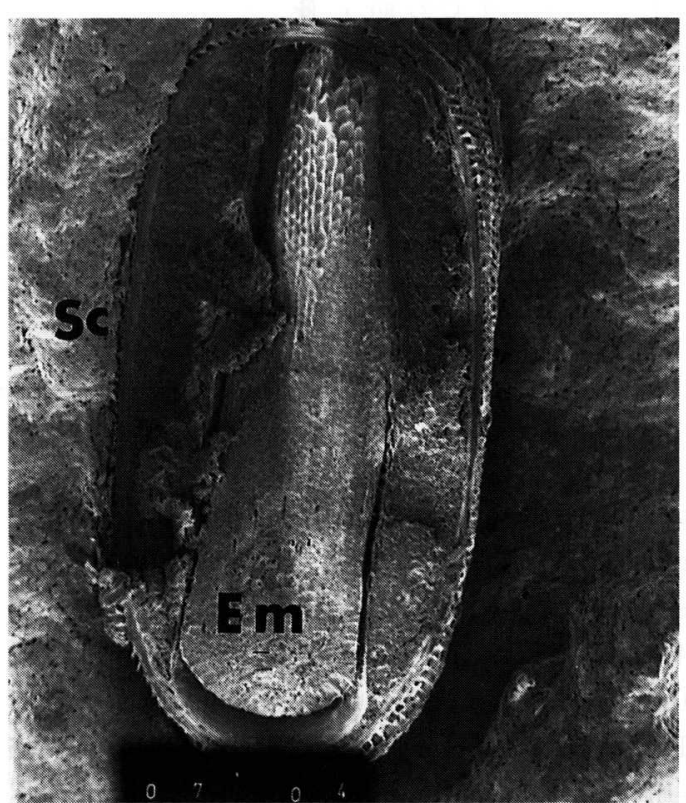

Fig. 3. Scanning electron micrograph of a longitudinal section of a Monochoria seed $(\times 85)$.

The seed was coated with gold immediately after harvest.

Em, Embryo; Sc, Seed coat. 
fold higher than the ambient level of $\mathrm{CO}_{2}$ in the atmosphere, meaning that an important factor regulating the evolution of ethylene is $\mathrm{CO}_{2}$ metabolism ${ }^{6,7,19)}$. Under the hypoxic conditions of a paddy field, germination of Monochoria seeds seems to be stimulated by the endogenous ethylene in the seeds, which is produced by exogenous $\mathrm{CO}_{2}$ in the atmosphere.

As reference data, Fig. 3 shows an electron micrograph of a longitudinal section of a Monochoria seed. The embryo was fully developed morphologically when the seed was harvested. If the seed was placed under low oxygen conditions the radicle appeared within 2-3 days, meaning that Monochoria seeds require low oxygen for radicle protrusion. But when grown under a low oxygen $(0.2 \%)$ concentration Monochoria seedlings were albino with abnormal roots ${ }^{1,9)}$.

Yamasue and $\mathrm{Ueki}^{1{ }^{18}}$ reported that seeds of Echinochloa oryzicola under the anaerobic condition showed good growth of the coleoptile with no radicle protrusion. In an extract from the seeds incubated in air, alcohol dehydrogenase activity decreased although there was no increase of cytochrome $c$ oxidase activity until the initiation of radicle growth. They therefore suggested that the radicle protrusion and growth were dependent on the aerobic respiration involving cytochrome $\mathrm{c}$ oxidase. Kordon ${ }^{11,12)}$ also found that over $90 \%$ of the rice seeds germinated in vacuo $\left(\mathrm{O}_{2}\right.$ deficit) within 7 days, although there was only coleoptile emergence with no greening or root emergence. Thus, the effect of oxygen on Monochoria seeds after germination may be related to biosynthesis of chlorophyll or normal growth of roots.

Acknowledgements : I wish to thank Mr. Hideo Chisaka, General Director of National Agricultural Research Center for giving me the opportunity to perform this research and making helpful comments and criticisms. Also, I thank Dr. Juanita A.R. Ladyman for helpful comments and critical review of the manuscript.

\section{References}

1) Chisaka, H. and T. Kataoka 1977. Physiological seed dormancy of annual lowland weeds (in Japanese). Weed Res., Japan 22(Suppl.), 9496.*

2) Esashi, Y. and H. Katoh 1975. Dormancy and impotency of cocklebur seeds. III. $\mathrm{CO}_{2}$-and $\mathrm{C}_{2} \mathrm{H}_{4}$-dependent growth of the embryonic axis and cotyledon segments. Plant Cell Physiol. 16, 707-718.

3) Esashi, Y. 1976. Mechanism of seed dormancy and germination. Seibutsu to Kagaku 15, 623633.*

4) Esashi, Y. 1990. Mode of regulation of seed dormancy and germination (2). Seibutsu to Kagaku 28, 390-398.*

5) Goodlass, G. and K.A. Smith 1978. Effect of $\mathrm{pH}$, organic matter content and nitrate on the evolution of ethylene from soils. Soil Biol. Biochem. 10, 193-199.

6) Grodzinski, B., I. Boesel and R.F. Horton 1982. Ethylene release from leaves of Xanthium strumarium L. and Zea mays L. J. Exp. Bot. 33, 344-354.

7) Jackson, M.B. 1985. Ethylene and responses of plants to soil waterlogging and submergence. Ann. Rev. Plant Physiol. 36, 145-174.

8) Kao, C.H. and S.F. Yang 1982 . Light inhibition of the conversion of 1-aminocyclopropane-1-carboxylic acid to ethylene in leaves is mediated through carbon dioxide. Planta 155, 261-266.

9) Kataoka, T. and S.Y.Kim 1978. Oxygen requirement for seed germination of several weeds. Weed Res., Japan 23, 9-12 (In Japanese with English summary).

10) Ketring, D.L. 1980. Ethylene and seed germination. In "The Physiology and Biochemistry of Seed Dormancy and Germination" ed. by A.A. Khan, North-Holland Pub. Co., Amsterdam, pp. 157-177.

11) Kordon, H.A. 1976. Rice seedlings germination in an in vacuo anaerobic environment. Ann. Bot. 40, 385-386.

12) Kordon, H.A. 1977. Latent effect of anaero-

* Translated from Japanese by the present author. 
biosis root growth in germinating rice seedlings. Plant Sci. Lett. 9, 53-56.

13) Levitt, J. 1980. Responses of plants to environmental stress. Vol II. Water, Radiation, Salt, and other stress. IInd edition, In "Physiological Ecology" A Series of Monographs, Texts, and Treatises, ed. by T.T. Kozlowski, Academic Press.

14) Robert E.H. 1973. Oxidative progress and the control of seed germination. In "Seed Ecology" ed. by W. Heydecker, Butterworths, London, pp. 189-218.

15) Ross J.D. 1984. Metabolic aspects of dormancy. In "Seed Physiology" vol. 2, Germination and reserve mobilization. ed. by D.R. Murrary,
Academic Press, New York, pp. 45-75.

16) Shibayama, H. 1988. Recent problems in paddy weed control (in Japanese). J. Agr. Sci. 44, 312-315.

17) Smith, K.A. and S.W.F. Restall 1971. The occurrence of ethylene in anaerobic soil. J. Soil Sci. 22, 430-443.

18) Yamasue, Y. and K. Ueki 1987. Seed dormancy and germination of Echinochloa oryzicola Vasing. : Substantive evidences for alcohol formation at early germination. Weed Res., Japan 32, 263-267.

19) Yang, S.F. and N.E. Hoffmann 1984. Ethylene biosynthesis and its regulation in higher plants. Ann. Rev. Plant Physiol 35, 155-189.

\section{$\mathrm{C}_{2} \mathrm{H}_{4}$ および $\mathrm{CO}_{2}$ がコナギ (Monochoria vagi- nalis var. plantaginea) 種子の発芽におよほ す影響}

\author{
桃木 芳枝*

\section{摘 要}

コナギ (Monochoria vaginalis var. plantaginea) 種子の発芽と，とくに土壌中の気相として想定され る $\mathrm{C}_{2} \mathrm{H}_{4}, \mathrm{CO}_{2}, \mathrm{O}_{2}$ とそれらを組み合わせたガス条件 との関係を検討した. 高発芽歩合は $\mathrm{C}_{2} \mathrm{H}_{4}$ と $\mathrm{CO}_{2}$ の 両方の存在によって認められ， $\mathrm{C}_{2} \mathrm{H}_{4}$ および $\mathrm{CO}_{2}$ の 両方の吸収剤が存在すると発芽歩合は著しく減少し た（Table 1)。 $\mathrm{CO}_{2}$ 吸収剂の存在下で外生的に与兄 た $\mathrm{C}_{2} \mathrm{H}_{4}$ は発芽を増加させたが，一方 $\mathrm{C}_{2} \mathrm{H}_{4}$ 吸収剂

\footnotetext{
* 東京農業大学生物産業学部
}

の存在下での外生的 $\mathrm{CO}_{2}$ の発芽への影響は極めて 小さかった。しかし, 外生的 $\mathrm{CO}_{2}$ 濃度の高い場合は 発芽歩合は高まった(Table 1)。これらのことから， コナギ種子の発芽は $\mathrm{CO}_{2}$ より $\mathrm{C}_{2} \mathrm{H}_{4}$ に影響される こと, また, 外生的に与えた $\mathrm{CO}_{2}$ 濃度の刺激で生成 される内生的 $\mathrm{C}_{2} \mathrm{H}_{4}$ により発芽が増加することが示 唆された。

さらに,コナギ種子は高酸素 $\left(60 \% \mathrm{O}_{2}\right)$ 下では発 芽歩合が著しく減少し, 低酸素 $\left(0.2 \% \mathrm{O}_{2}\right)$ 下では高 い発芽歩合を示した（Fig. 2)。事実，休眠覚醒した 種子でさえ通気状態でろ紙を敷いたぺトリ皿では発 芽が認められなかった(Fig. 1)。これらのことは, コ ナギ種子の発芽にはほとんど酸素を必要としないこ とを証明している。

キーワード：エチレン, コナギ種子, 酸素, 二酸化 炭素, 発芽. 